\title{
The Structure and Pathologies of Local Selective Procurement Ordinances: A Study of the Apartheid-Era South Africa Ordinances
}

\author{
By
David D. Caron*
}

The wisdom and legality of city participation in the foreign affairs of the United States has been long debated and studied. In the past few years, this debate has centered on actions taken by local governments to express their concerns regarding the human rights practices of Myanmar, formerly referred to as Burma. The proceedings in Crosby v. National Foreign Trade Council provided a focal point for this debate as it wound its way upward through the courts. ${ }^{1}$ During the 1980s, a similar debate had centered on the actions of cities who took roughly the same set of actions to express their concerns with the system of apartheid then in place in South Africa.

At the close of the 1980s, I undertook a study of the selective procurement ordinances adopted by cities and counties in the United States as indirect sanctions of South African apartheid regime. For several reasons, the project was put aside and over time the project dropped into the background of my research. It was my interest in the fascinating questions presented by sub-national foreign policy that led me as Chair of the AALS International Law Section to organize

* C. William Maxeiner Distinguished Professor of Law, University of California at Berkeley, Boalt Hall School of Law and Chair, International Law Section, American Association of Law Schools, 2000-2001. I wish to acknowledge the assistance during the original research of Peter Root, Joseph Giansiracusa, Tal Herman, Janelle London, and Paul Startz; the support of the Committee on Research of the University of California at Berkeley; and, most recently, the assistance of Laura Altieri. The ordinances and background documents described in this essay are on file with the author.

1. The 1996 Massachusetts "Burma Law," codified at MAss. GÉN LAws ch. 7, \$§ 22G-22M and $40 \mathrm{~F} 1 / 2$ (West Supp. 1998) was challenged by the National Foreign Trade Council (NFTC) as (1) preempted by federal sanctions against Burma imposed under the authority of the Omnibus Consolidated Appropriations Act of 1997, Pub. L. No. 104-208, § 570, 110 Stat. 3009, 3009-166- 167, (2) violative of the dormant foreign commerce clause of the Constitution, and (3) intrusive on the federal government's exclusive foreign affairs power. The District Court found the burden of preemption to not be established, but ruled in favor of the NFTC on the two Consititutional bases. NFTC v. Baker, 26 F. Supp. 2d 287 (D. Mass. 1998). The First Circuit Court of Appeals affirmed the district court decision, adding its conclusion that the law also was preempted by the federal actions vis-à-vis Burma in NFTC v. Natsios, 181 F.3d 38 (1st Cir. 1999). The Supreme Court in NFTC v. Crosby, 530 U.S. 363 (2000), affirmed the lower decisions, resting its decision solely on the preemption grounds. 
its 2001 Panel around the Crosby decision and the local sanctions adopted with regard to Burma. At the very last moment, one of the panelists was unable to participate and that absence provided the opportunity for me to revisit my earlier project both in terms of what was learned then and the perspective it gives on Crosby. For this opportunity, I am thankful.

The work I undertook in the 1980s was unusual in that it attempted to explain what the cities were, in fact, doing. The motivation behind the choice of that approach deserves mention.

In the case of local governmental action regarding South Africa (and Burma also), there were two main types of action. First, there were ordinances requiring the divestment of public holdings of stocks in firms related in specified ways to the South Africa. ${ }^{2}$ Second, and less present in practice or literature, there were ordinances restricting the procurement of goods and services where the bidder for a city contract had a specified relationship with South Africa. ${ }^{3}$

Much has been written about the role of municipalities in the foreign affairs of the United States. ${ }^{4}$ But that body of writing, for the reasons which follow, was not satisfying in explaining several important aspects of what was happening with the actions regarding South Africa.

The substantial legal literature analyzed the limited number of textual sources and decisions that existed on the constitutionality of such actions. ${ }^{5}$ Although the literature tended to be quite confident of the law (one way or the other), there was in fact no litigation and that made the extensive analysis seem oddly irrelevant. No cases like Crosby were brought, although industry and the federal government were most certainly aware of the arguments to be made.

2. The scholarly literature regarding South African divestment was quite substantial. See, e.g., John H. Langbein, Social lnvesting of Pension Funds and University Endowments: Unprincipled, Futile and Illegal, in Disinvestment: Is it Legal? Is it Moral? Is it Productive? I (J. Langbein, R. Schotland, and A. Blaustien, eds. 1984); Grayling M. Williams, In Support of Azania: Divestiture of Public Pension Funds as One Answer to United States Private Investment in South Africa, 9 BLACK L.J. 167-187 (1985); Grace A. Jubinsky, State and Municipal Governments React Against South African Apartheid: An Assessment of the Constitutionality of the Divestment Campaign, 54 Cincinnati L. Rev. 543-578 (1985); Jennifer Davis, et al., Economic Disengagement and South Africa: The Effectiveness and Feasibility of Implementing Sanctions and Disinvestment, 15 LAw \& Pol'y IN INT'L Bus. 529 (1983). See also Valerie Lezin \& Lauren Milicov, Divestment from South Africa: Public Protest v. Public Trust, L.A. LAw., Nov. 1985, at 12.

3. A third and uncommon type of action is contained in the Los Angeles selective purchasing ordinance and might be more appropriately described as a selective dealing ordinance. A provision of that ordinance prohibited the awarding of leases on city land to anyone who does business with South Africa. Since many pipelines of oil and natural gas, for example, are on lands leased from local governments, operation of the ordinance when a lease was up for renewal potentially posed a much greater issue for such business than the awarding of a particular procurement contract.

4. For a particularly valuable piece published during the time of this study, see Peter J. Spiro. State and Local Anti-South African Action as an Intrusion upon the Federal Power in Foreign Affairs, 72 VA. L. REv. 813 (1986).

5. A central and contested precedent in this area is the U.S. Supreme Court decision in Zschernig v. Miller, 389 U.S. 429 (1968). In that case, the Court struck down a state statute that it found to be precluded by the dormant foreign affairs clause in that the statute "affects international relations in a persistent and subtle way." Id,. at 440 . The dissent in Zschernig, among other things, pointed to the seemingly indistinguishable holding of the Court in Clark v. Allen, 331 U.S. 503 (1947), a mere twenty-one years earlier and involving a similar state statute. 
Everyone conceded that Congress could explicitly preempt local action, but that did not occur either. Municipal foreign affairs is an arena of strange contrasts. On the one hand, the Constitution is said to be very clear prohibiting "state involvement in foreign affairs and international relations-matters which the Constitution entrusts solely to the Federal Government. . .." On the other hand, in the course of conducting interviews that underlie this study, it was apparent that law (constitutional or otherwise) had little effect on what the municipalities were willing to do or what they got away with. Although our Constitution places the conduct of foreign relations in the hands of the Executive and Congress, the day to day reality is not so clear. Given this separation of law from practice, the literature seemingly had nowhere to go. For the most part, it was set off in a circle referencing itself and piling on to one side or the other.

Throughout this literature, assumptions were made about what these ordinances provided, how they might bring about change in South Africa, how they were an expression of a truer democracy, how they were harmful to business, and how they interfered with the foreign affairs power of the federal government. Yet, there was little analysis of what the local actions precisely prescribed and what impact they had on bidders, the local municipality, the foreign affairs of the United States or the policies of the target country. My project undertook to find out more about the ordinances, what they provided and how they operated in practice. The project was not about the Constitution, but rather the ordinances themselves. And, for me, the ordinances presented surprises.

The research that was set aside in 1989 is offered here, not as a complete answer to the questions posed, but as a snapshot of the selective procurement ordinances through approximately 1988. Part I sets forth the facts. I describe the method I employed and the set of ordinances this study reviews. The structures of thirty-six ordinances are compared with particular attention to patterns apparent in those structures. Part II offers seven observations about the ordinances described in Part I. In Part III, I bring the experience of this project to bear on the implications of the recent Crosby decision.

I.

Structure ANd PATterns

\section{A. The Ordinances}

This study focuses on selective procurement ordinances adopted by local governments as an expression of their opposition to the system of apartheid then in place in South Africa. Selective procurement ordinances are sometimes referred to as "anti-procurement" ordinances; I prefer the term "selective procurement" because, as this study makes clear, the term "anti-procurement" overstates the strength of most of the ordinances.

An initial, and by no means easy, task in this study was to identify the various local governments that were said to have had selective procurement or-

6. Zschernig, 389 U.S. at 436 (1968). 
dinances and to collect such laws. Drawing from the mention of particular cities in the news, from lists prepared by organizations advocating the adoption of such ordinances and from consulting firm surveys, this study ultimately confirmed thirty-six laws ${ }^{7}$ that restricted procurement of goods or services where the transaction or the bidders had a specified relationship with South Africa. ${ }^{8}$ These ordinances and their originating jurisdictions are summarized in Table 1. This Part sets forth the results of a comparative analysis of these ordinances. Observations based on that analysis are offered in Part II.

Table 1 - Local Ordinances Considered in this Study

\begin{tabular}{|c|c|c|c|c|}
\hline State & $\begin{array}{l}\text { MUNICIPALITY OR } \\
\text { COUNTY }\end{array}$ & $\begin{array}{c}\text { SIZE OF CITY } \\
\text { IN TERMS OF } \\
\text { POPULATION } \\
\text { IN THE MID } \\
\text { 1980s }\end{array}$ & $\begin{array}{c}\text { YEAR } \\
\text { ORDINANCE } \\
\text { ADOPTED }\end{array}$ & Citation \\
\hline Arizona & Tucson & $\begin{array}{l}>100,000 \\
<500,000\end{array}$ & 1985 & $\begin{array}{l}\text { Tucson, Ariz., Report on Investments } \\
\text { in Firms Doing Business in South } \\
\text { Africa (adopted Sept. 3, 1985). }\end{array}$ \\
\hline \multirow[t]{4}{*}{ Califomia } & Alameda County & Not applicable & 1986 & $\begin{array}{l}\text { Alameda County, Cal., Ordinance 01- } \\
\text { 28-86 (Jan. 28, 1986). }\end{array}$ \\
\hline & Berkeley & $\begin{array}{l}>100,000 \\
<500,000\end{array}$ & 1986 & $\begin{array}{l}\text { Berkeley, Cal., Resolution } 53080 \\
\text { (January } 7,1986) \text {. }\end{array}$ \\
\hline & Los Angeles & $>500,000$ & 1987 & $\begin{array}{l}\text { Los Angeles, Cal., Ordinance } 162336 \\
\text { (May } 1,1987 \text { ). }\end{array}$ \\
\hline & Oakland & $\begin{array}{l}>100,000 \\
<500,000\end{array}$ & 1985 & $\begin{array}{l}\text { Oakland, Cal., Ordinance } 10611 \text { (July } \\
\text { 23. 1985). }\end{array}$ \\
\hline
\end{tabular}

7. One of these "laws" is a state statute. For the sake of convenience, they hereinafter are referred to collectively as "ordinances."

8. Some limitations to the completeness of this list should be noted.

First, a number of cities mentioned in the press or included on a list prepared by the business community or a non-governmental organization did not in fact have such an ordinance. Why this might be the case is discussed in the text in Part II. All states, counties and cities listed were contacted and in a few instances the local governmental entity replied that such an ordinance had not been adopted by the city or county. For example, the Washington Post reported in a 1986 story that "[a]t least 31 local governments and two states [Michigan and Maryland] have passed [selective procurement ordinances] during the past twelve months." See Local Boycotts Power Pullouts by U.S. Business, WASH. Post, Nov. 17, 1986, at AI, [hereinafter "Local Boycotts"]. I was never able to confirm that Michigan had a selective procurement statute. In some instances, the circumstance appears primarily to be a result of others mistakenly characterizing a divestment ordinance as one dealing with selective procurement. Some lists, for example, indicated that Kansas City, Missouri, had a selective procurement ordinance. Kansas City did adopt Resolution 58323 on August 29, 1985. Although that ordinance calls on businesses to reconsider their relationships with South Africa, it contains no discussion regarding procurement and is thus not included in this study. Similarly two cities and two counties that were said to have selective procurement ordinances, to the best of my knowledge, did not. Ordinances for these cities and counties did prohibit the provision of public funds to certain financial institutions and may therefore have been confused with selective procurement ordinances. The four local governments and their ordinances are New Orleans, La., Ordinance 10593 (May 23, 1985), St. Paul, Minn., Resolution 86-948 (July 10, 1986); New Castle County, Del., Ordinance 86-005 (Jan 31, 1986); and Prince George's County, Md., CounTy Code Subtitle 10, § 10-117.1 (1983).

Second, although there is substantial confidence that the list in Table 1 is complete, particularly through the year 1987, it is quite possible that further ordinances were adopted in the closing years of the apartheid era in South Africa. The selective procurement ordinance adopted by the city of Berkeley, CA was not ended until October 19, 1993. Sasha Thurman, City Votes to End 14-year South Africa Sanctions, Daily Californian, Oct. 22, 1993, Ordinances not listed or corrections to those included are welcome from readers of this study. 


\begin{tabular}{|c|c|c|c|c|}
\hline \multirow[t]{7}{*}{$\begin{array}{l}\text { California } \\
\text { (cont'd) }\end{array}$} & Richmond & $<100.000$ & 1985 & $\begin{array}{l}\text { Richmond, Cal., Ordinance } 10-86 \text { (Feb. } \\
10,1985 \text { ). }\end{array}$ \\
\hline & Sacramento & $\begin{array}{l}>100,000 \\
<500,000\end{array}$ & 1987 & $\begin{array}{l}\text { Sacramento, Cal., Ordinance } 87-030 \\
\text { (April 27, 1987). }\end{array}$ \\
\hline & San Diego & $>500,000$ & 1987 & $\begin{array}{l}\text { San Diego, Cal., Ordinance } 268530 \\
\text { (June } 8,1987 \text { ). }\end{array}$ \\
\hline & San Francisco & $>500.000$ & 1986 & $\begin{array}{l}\text { San Francisco, Cal., Ordinance } 36-86 \\
\text { (Jan. 21, 1986). }\end{array}$ \\
\hline & Sonoma County & Not applicable & 1989 & $\begin{array}{l}\text { Sonoma County, Cal., Ordinance } 86- \\
0201 \text { (Feb 8, 1989). }\end{array}$ \\
\hline & Stockton & $\begin{array}{l}>100,000 \\
<500,000 \\
\end{array}$ & 1985 & $\begin{array}{l}\text { Stockton, Cal., Ordinance } 85-0335 \\
\text { (May } 13,1985 \text { ). }\end{array}$ \\
\hline & West Hollywood & $\begin{array}{l}>100,000 \\
<500,000 \\
\end{array}$ & 1986 & $\begin{array}{l}\text { West Hollywood, Cal., Ordinance } 100 \\
\text { (Feb. 6, 1986). }\end{array}$ \\
\hline Colorado & Fort Collins & $<100,000$ & 1985 & $\begin{array}{l}\text { Fort Collins, Colo., Resolution 85-134 } \\
\text { (August } 20,1985 \text { ). }\end{array}$ \\
\hline Illinois & Chicago & $>500,000$ & 1986 & $\begin{array}{l}\text { Chicago, Ill., Ordinance } 26-26.2 \text { (April } \\
4,1986 \text { ). }\end{array}$ \\
\hline Indiana & Gary & & 1985 & $\begin{array}{l}\text { Gary, Ind., Resolution } 1869 \text { (Jan. } 8 \text {, } \\
\text { 1985). }\end{array}$ \\
\hline \multirow[t]{2}{*}{ Kansas } & Kansas City & $\begin{array}{l}>100,000 \\
<500,000\end{array}$ & 1985 & $\begin{array}{l}\text { Kansas City, Kan., Resolution } 36179 \\
\text { (Oct. 17, 1985). }\end{array}$ \\
\hline & Topeka & $\begin{array}{l}>100,000 \\
<500,000\end{array}$ & 1986 & $\begin{array}{l}\text { Topeka, Kan., Resolution } 5232 \text { (Jan. } \\
\text { 28, 1986). }\end{array}$ \\
\hline \multirow[t]{2}{*}{ Maryland } & State of Maryland & Not applicable & 1986 & $\begin{array}{l}\text { State of Maryland State Finance and } \\
\text { Procurement Code, } \$ 14-501 \text { et seq. } \\
\text { (May 27, 1986, amended 1988) }\end{array}$ \\
\hline & College Park & $<100,000$ & 1985 & $\begin{array}{l}\text { College Park, Md., Resolution 85-R-2 } \\
\text { (April 23, 1985). }\end{array}$ \\
\hline Michigan & East Lansing & $<100,000$ & 1977 & $\begin{array}{l}\text { East Lansing, Mich., Resolution on } \\
\text { South Africa (August 3, 1977). }\end{array}$ \\
\hline Minnesota & Hennepin County & Not applicable & 1985 & $\begin{array}{l}\text { Hennepin County, Minn., Resolution } \\
\text { 85-12-863 (Dec. 10, 1985). }\end{array}$ \\
\hline Nebraska & Omaha & $\begin{array}{l}>100,000 \\
<500,000 \\
\end{array}$ & 1985 & $\begin{array}{l}\text { Omaha, Neb., Resolution } 30823 \text { (Oct. } \\
8,1985 \text { ). }\end{array}$ \\
\hline \multirow[t]{2}{*}{ New Jersey } & Camden & $<100,000$ & 1985 & $\begin{array}{l}\text { Camden, N.J.. Resolution Condemning } \\
\text { the Violation of Human Rights in } \\
\text { South Africa and Namibia and } \\
\text { Directing the Divestment of Economic } \\
\text { Interests (Sept., 12, 1985). }\end{array}$ \\
\hline & Newark & $\begin{array}{l}>100,000 \\
<500,000\end{array}$ & 1984 & $\begin{array}{l}\text { Newark, N.J., Ordinance 6STFBC (Oct. } \\
3,1984 \text { ). }\end{array}$ \\
\hline \multirow[t]{3}{*}{ New York } & New York & $>500,000$ & 1985 & $\begin{array}{l}\text { New York City, N.Y., Local Law } 19 \text { of } \\
1985 \text {, Council Int. No. } 900 \text { (1985). } \\
\text { New York City, N.Y., Resolution 92- } \\
1985 \text { (March 26, 1985). }\end{array}$ \\
\hline & Rochester & $\begin{array}{l}>100,000 \\
<500,000\end{array}$ & 1985 & $\begin{array}{l}\text { Rochester, N.Y., Ordinance 85-133 } \\
\text { (1985) }\{\text { N.d.\}. }\end{array}$ \\
\hline & Yonkers & $\begin{array}{l}>100,000 \\
<500,000\end{array}$ & 1985 & $\begin{array}{l}\text { Yonkers Resolution 92-1985 (adopted } \\
\text { Mar. } 26 \text { 1985) }\end{array}$ \\
\hline North Carolina & Raleigh & $\begin{array}{l}>100,000 \\
<500,000\end{array}$ & 1985 & $\begin{array}{l}\text { Raleigh, N.C., Resolution 1986-62 (Jan. } \\
21,1986 \text { ). }\end{array}$ \\
\hline Pennsylvania & Pittsburgh & $\begin{array}{l}>100,000 \\
<500,000\end{array}$ & 1985 & $\begin{array}{l}\text { Pittsburgh, Pa., Ordinance } 1929 \text { (Feb. } \\
12,1985 \text { ). }\end{array}$ \\
\hline South Carolina & Charleston & $<100,000$ & 1985 & $\begin{array}{l}\text { Charleston, S.C., Resolution (August } \\
\text { 20, 1985). [no title nor number] }\end{array}$ \\
\hline Texas & Houston & $>500,000$ & 1986 & $\begin{array}{l}\text { Houston, TX., Ordinance } 86-1279 \text { (July } \\
23,1986 \text { ) and Ordinance } 86-1312 \text { (July } \\
30,1986 \text { ) }\end{array}$ \\
\hline
\end{tabular}




\begin{tabular}{|l|l|c|c|l|}
\hline Virginia & Richmond & $\begin{array}{l}>100,000 \\
<500,000\end{array}$ & 1986 & $\begin{array}{l}\text { Richmond, VA Resolution 85-R344- } \\
\text { 313 (Jan. 13, 1986). Ordinance 10-86 } \\
\text { (Feb. 10, 1986). }\end{array}$ \\
\hline & Washington, D.C. & $>500,000$ & $1986-5$ & $\begin{array}{l}\text { Washington, D.C., 6-116 (1986). } \\
\text { Washington, D.C., Code, \& 1-1181.1 et } \\
\text { seq. (1987 supp.). }\end{array}$ \\
\hline West Virginia & Fairmont & $<100,000$ & 1986 & $\begin{array}{l}\text { Fairmont, W.V., Resolution (June 17, } \\
\text { 1986). }\end{array}$ \\
\hline Wisconsin & Madison & $\begin{array}{l}>100,000 \\
<500,000\end{array}$ & 1976 & Resolution 29,355 (June 29, 1976) \\
\cline { 2 - 5 } & Milwaukee & $>500,000$ & 1985 & $\begin{array}{l}\text { Milwaukee, Wis., Resolution 84-1514 } \\
\text { (Feb. 12, 1985). }\end{array}$ \\
\hline
\end{tabular}

\section{B. The Framework of Analysis}

In analyzing the ordinances that restricted procurement from bidders with specified relationships to South Africa, four aspects of the ordinances are compared by this study.

First, the study examines the circumstances which trigger application of a selective purchasing regime vis-à-vis a particular bidder or transaction. Selective procurement ordinances restrict procurement from bidders that are in some way thought to be supportive of, or benefiting from a relationship with, the target country. But how is this relationship with the target country specified in the ordinance? A few ordinances are vague on the point. But in general, the South Africa ordinances looked to whether the goods offered originated in South Africa, whether the bidder itself or its suppliers complied with the Sullivan Principles, ${ }^{9}$ whether the bidder did business with Apartheid-enforcing agencies, or, most broadly, whether the bidder did business in or with South Africa.

Second, the study compares the nature and degree of the resulting prohibition on procurement. Assuming that a particular bidder did have the relationship

9. The Sullivan Principles refer to "a corporate code designed in 1977 by Reverend Sullivan, a West Virginia minister and then a member of the General Motors Board of Directors, to help eliminate apartheid by obligating American corporate signatories to eliminate racial inequities within their South African operations." Robert R. Kuehn, Access to Justice: The Social Responsibility of Lawyers-Denying Access to Legal Representation. The Attack on the Tulane Environmental Law Clinic, 4 WASH. U.J.L. \& POL'Y 33, 119 n.410 (2000). These Principles were amended and refined, and continue today as a code of principles for businesses operating anywhere in the world. Leon Sullivan more recently wrote:

The objectives of the Global Sullivan Principles are to support economic, social and political justice by companies where they do business; to support human rights and to encourage equal opportunity at all levels of employment, including racial and gender diversity on decision making committees and boards; to train and advance disadvantaged workers for technical, supervisory and management opportunities; and to assist with greater tolerance and understanding among peoples; thereby, helping to improve the quality of life for communities, workers and children with dignity and equality. I urge companies large and small in every part of the world to support and follow the Global Sullivan Principles of Social Responsibility wherever they have operations.

Available at, http://globalsullivanprinciples.org/principles.htm (last visited 10/30/2002). See also Arthur D. Little, Inc., "Communications Task Group of the Sullivan Signatory Companies, Meeting the mandate for change: a progress report on the application of the Sullivan principles by U.S. companies in South Africa" (1986); Arthur D. Little, Inc., "Report on the signatory companies to the Sullivan principles," (1986); Christopher McCrudden, Human Rights Codes for Transnational Corporations: What Can the Sullivan and MacBride Principles Tell Us?, 19 OxFord J. LeGal Stu. 167-201 (1999). 
of concern with the target country, what was the sanction prescribed by the ordinance? Although in some cases the consequence would be that the local government could not award the procurement contract to the bidder in question (what is called in this study a "total prohibition"), other ordinances instead gave a preference to complying companies, others required only a statement of concern and some were simply unclear as to what was to happen. Moreover, in those ordinances which contained a "total prohibition," there were in many cases exceptions to the total prohibition.

Third, the study examines the mechanisms employed by the various ordinances to identify whether a bidder or transaction had the specified relationship to South Africa which would trigger application of the ordinance. Again, a few ordinances were unclear as to how tainted bidders were to be identified. The remaining ordinances provided for either a listing of companies maintained by some institution or some form of statement from all bidders as to the origin of the goods or as to the bidder's relationship with South Africa.

Finally, this study compares the degree to which the ordinances examined the relationships to South Africa of not only the bidder, but possibly also the bidder's parent company, subsidiaries, affiliates, subcontractors or suppliers.

The following four sections examine each of these four aspects in greater detail. Examples are provided as to the language utilized in the various ordinances. The language of the San Francisco ordinance is cited in particular because that ordinance was one of the last passed in the time frame of this study and, arguably, was the most detailed.

\section{The Link to South Africa}

In approaching the selective procurement ordinances, a fundamental point to investigate is which aspect of a possible purchase triggered the local government's concern. In this section, I summarize how the ordinances themselves identified certain transactions as the ones of concern. Broadly speaking, the trigger was defined by one of four tests. ${ }^{10}$ These tests to varying degrees encompassed the possible relationships a bidder might have with South Africa. As with contemporary discussions on the design of smart sanctions, the various tests targeted relationships more or less close to the core of concern with South Africa, i.e., the apartheid system. Many of these local sanctions were opposed on the grounds that they would not alter South Africa, but only injure U.S. business. It is therefore perhaps not surprising that some of the triggers for selective procurement regimes were quite narrow and limited the application of the ordinance to affect only those who most benefit from the apartheid system.

One of the narrower tests focused on the agencies by which apartheid was upheld. In particular, seven of the thirty-six ordinances focused, among other things, on purchases from bidders who did business with specific apartheid-en-

10. In addition to the four tests discussed in the text, two of the ordinances, Charleston, SC, and Milwaukee, WI, were vague as to what circumstances would trigger application of the prohibition. For example, Charleston, SC, applied prohibitions to companies that "support the apartheid system through their investments in South Africa." 
forcing agencies in South Africa. ${ }^{11}$ These agencies included the South African (1) Police, (2) Military, (3) Prison Department and (4) Department of Cooperation and Development. Here the bidders were thought to be profiting from business with the institutions directly sustaining apartheid.

The other relatively narrow test focused on whether the bidder itself, and in some instances the supplier to the bidder, operated its business in South Africa in accordance with the Sullivan Principles. Five of the ordinances identify non compliance with these Principles by the bidder as a trigger for application of the ordinance. ${ }^{12}$ In the Maryland statute, for example, non-compliance with the Principles is listed as a possible triggering circumstance. ${ }^{13}$ Under that statue the bidder must certify that "in the conduct of operations in the Republic [of South Africal or Namibia" it

(1) maintains nonsegregation of the races in all eating, comfort and work facili-

ties and locker rooms;

(2) promotes equal and fair employment ...;

(3) provides equal pay. ..;

(4) initiates and develops training programs that will prepare . . nonwhites for supervisory, administrative, clerical and technical jobs;

(5) increases the number of . . . nonwhites in management and supervisory positions; and

(6) improves the quality of employee's lives outside the work environment. ${ }^{14}$

Before describing the two relatively broader tests, it is important to note that the narrower tests generated information about bidders and that such information itself had implications. An example of this was the acrimonious battle between Xerox Corporation and Eastman Kodak for business with New York City. Both companies had business activity in South Africa at the time. Both also stated, however, that they did not do business with the Apartheid enforcing agencies there: the relevant trigger under the City's ordinance. The ordinance was not strictly applicable. However, the process of educating the City as to the extent of their operations in South Africa itself began to generate its own political dynamic. A Xerox official was reported to have said that " $[t]$ he whole discussion became: who's the better person in South Africa."15

The remaining two tests are broader in the sense that they relate to South Africa generally. They appear to flow from the view that reform would come not from a focus solely on the institutions or practices of the apartheid system, but rather pressure generally on South Africa. One trigger of this broad view involved a quite limited number of purchase situations in practice. This trigger focused on the source of the goods to be purchased. If the goods were produced

11. Five of these ordinances are quite detailed and appear to follow the model set by the March 1985 New York City ordinance. These five ordinances are Fort Collins, CO; Chicago, IL; New York, NY; Yonkers, NY; and Houston, TX. The two further resolutions are also similar, but also briefer. They are the ordinances for Rochester, NY, and Raleigh, NC.

12. The State of Maryland; and the cities/county of Rochester, NY; Fort Collins CO; Hennepin County, MN; and Raleigh, NC. For all except Hennepin County, the prohibition trigger extends also to the suppliers of the bidder.

13. Maryland Statute, § 14-503.

14. Id.

15. See Local Boycotts, supra note 8. 
in South Africa, even by a company in full compliance with the Sullivan Principles, the application of the ordinance was triggered. I term this a limited example because in fact South Africa produced few goods that might be purchased by local governments in the United States. Twelve of the thirty-six ordinances used the South African origin of the goods as a trigger. ${ }^{16}$ The College Park, MD, ordinance, for example, provided that "the City Administrator is hereby directed to make no further purchases of goods or services originating in the Republic of South Africa." These twelve overlap with the previously described ordinances because ordinances with a South African goods trigger tended to have at least one other trigger. Only four of the twelve ordinances do not have some other trigger as well. ${ }^{17}$

It is the remaining broad trigger that was employed in most of the ordinances. Although the precise wording varies, twenty-four of the thirty-six ordinances focused on whether the bidders did business, broadly speaking, in or with South Africa. ${ }^{18}$ Although the definition of "doing business" is obviously critical to understanding this test, only a few of the twenty-four ordinances provide one. The San Francisco ordinance provides the most detailed statement of this type of trigger. Under the San Francisco ordinance, the City is prohibited from purchasing any commodity from:

(1) the government of South Africa;

(2) a business organized under the laws of South Africa;

(3) any person or entity doing business in South Africa. ${ }^{19}$

The implementing regulations for the San Francisco ordinance go on to define an entity as "doing business" in South Africa if the entity:

(1) is organized under the laws of South Africa;

16. Sacramento, CA; Stockton, CA; Fort Collins, CO; Chicago, IL; The State of Maryland; College Park, MD; Omaha, NE; New York, NY; Rochester, NY; Yonkers, NY; Raleigh, NC; and Houston, TX.

17. Sacramento, CA; Stockton, CA; College Park, MD; and Omaha, NE.

18. Tucson, AZ ("conducting business with South Africa"); Alameda, CA (list of American companies doing business in South Africa); Berkeley, CA; Los Angeles, CA ("doing business in or with South Africa"); Oakland, CA (list of American companies doing business in South Africa); Richmond, CA ("does business in or with South Africa or Namibia"); San Diego, CA ("companies which have business operations in South Africa"); San Francisco, CA ("entity doing business in South Africa"); Sonoma County, CA (business in the Republic of South Africa or Namibia"); West Hollywood, CA ("business in or with in the Republic of South Africa or Namibia"); District of Columbia ("on the prohibited list or *** doing business in or with *** South Africa or Namibia"); Gary, IN ("doing business in South Africa"); Kansas City, KS ("business in or with *** South Africa"); Topeka, KS ("business in or with *** South Africa"); Hennepin County, MD ("direct business involvement within the Republic of South Africa"); East Lansing, MI ("investments, licenses or operations in South Africa"); (Camden NJ ("operating in * * * South Africa or Namibia"); Newark, NJ ("having investments, licenses or operations in *** South Africa or Namibia"); Pittsburgh, PA ("any contractual arrangements [with or] actually operating in *** South Africa or Namibia"); Charleston, SC ("companies *** that support the apartheid system through their investments in South Africa"); Richmond, VA (doing business with entities in South Africa); Fairmont, WV ("which provides services to the Republic of South Africa, any instrumentality or agent thereof"); Milwaukee, WI ("business relationship with or in the Republic of South Africa") and Madison, WI ("economic interests in South Africa").

19. The City was also prohibited from purchasing any commodity manufactured, produced or grown in South Africa. 
(2) does business with another business entity for the express purpose of assisting the second entity's operations or trading with an public or private entity located in South Africa;

(3) has an agent, employee or authorized representative in South Africa;

(4) owns property in South Africa;

(5) permits its trademark, copyright or patent to be used by an entity in South Africa;

(6) has an office in South Africa;

(7) has ownership or control of an "Associated Entity" which is doing business in South Africa;

(8) has a direct buyer of goods or services located in South Africa;

(9) is a seller of commodities and knows or should know the buyer will resell the commodities to another entity in South Africa, or will use the commodity in furtherance of its South Africa business operations. ${ }^{20}$

\section{The Prohibition}

We have seen that a variety of circumstances triggered application of the various ordinances. One might think that, once triggered, a selective procurement ordinance would bar the particular local government from entering into the particular transaction. This would be a mistake. Indeed, to the contrary, there was a wide range in severity of the restrictions on procurement from tainted bidders.

Table 2 - The Nature and Degree of the Prohibition

\begin{tabular}{|c|c|c|c|}
\hline Total Prohibition & Preference & $\begin{array}{c}\text { Mayoral } \\
\text { Statement } \\
\text { Of Concern }\end{array}$ & Unclear \\
\hline 22 of the 36 & 9 of the 36 & 2 of the 36 & 3 of the 36 \\
$\begin{array}{c}15 \text { are quite detailed or quite clear in } \\
\text { the choice of atotal prohibition } \\
\text { appearing to prohibiting procurement }\end{array}$ & $\begin{array}{l}\text { contain only a general statement } \\
\text { awarded in contract evaluation } \\
\text { I assigns demerits but with a \% cap } \\
\text { to the effect of such demerits } \\
2 \text { provide a preference in the event } \\
\text { of low tied bids }\end{array}$ & & \\
\hline
\end{tabular}

The strongest sanction in the ordinances reviewed was a total prohibition on procurement from specified bidders. Twenty-two of the thirty-six ordinances had a total prohibition, restricting outright the granting of purchase orders to tainted companies. Fifteen of these twenty-two ordinances were relatively clear and the sanction appeared to be one made seriously. ${ }^{21}$ However, the other seven of these twenty-two ordinances were so brief, and either so vague or phrased in such general terms, that the seriousness of the procurement bar is questionable and difficult to assess. ${ }^{22}$ For example, these latter ordinances often did not in-

20. San Francisco, Cal., Regulations Governing the Implementation of Article XIX of the San Francisco Administrative Code (October 19, 1987) at 8, para. 3.

21. Berkeley, CA; Los Angeles, CA; Richmond, CA; San Diego, CA; San Francisco, CA; West Hollywood, CA; Chicago, IL; State of Maryland, College Park, MD; Raleigh, NC; Omaha, NE; Newark, NJ; Pittsburgh, PA; Houston, TX; and Fairmont, WV.

22. Camden, NJ; Charleston, SC; Gary, IN; Rochester, NY; Stockton, CA; Tucson, AZ; and Richmond, VA. 
clude any exceptions to the prohibition, or provide a clear definition of the circumstances that would trigger application of the prohibition.

Nine of the thirty-six ordinances, instead of prohibiting procurement, provided a preference in awarding contracts to bidders who were not regarded as tainted by their relationship to South Africa. Six of these nine ordinances provided a specific percentage preference formula. ${ }^{23}$ The preferences embodied in the remaining three ordinances are less obvious. The Washington, D.C. ordinance, for example, provided for the assignment of "demerits" to tainted bidders and the consideration of such demerits as a negative factor, weighing against the award of the contract. ${ }^{24}$ The negative impact accorded demerits, however, could not exceed six percent of the lowest bid. ${ }^{25}$ The remaining two ordinances essentially provided that a preference for the untainted bidder should be given in the event of "low-tied bids." 26

A subtle twist involves the transformative effect of exceptions on the prohibition. Two of the fourteen serious "total prohibition" ordinances contained an exception to their application if the resultant cost to the city exceeded a specified percentage. ${ }^{27}$ In effect, these two ordinances operated in a similar fashion to a contract preference. Moreover, many of the total prohibition ordinances operated under some unspecified cap on the possible loss to the city involved. The Raleigh, NC, ordinance, for example, provided for a total prohibition "unless no reasonable $* * *$ alternative" existed.

Yet a further two ordinances (the earliest in this study, adopted in 1976 and 1977) required only that the Mayor include a statement of concern on all invoices and bids. ${ }^{28}$ For example, in the case of the Madison, WI ordinance, the Mayor was to attach to all contracts where the bidder had "economic interests in South Africa" the following statement:

The City of Madison wishes to express its grave concern about your company's policy of developing economic interests in the Republic of South Africa and its apartheid system. The great moral issue involved is forcing us to seek competitive suppliers for this product or service in future transactions.

Finally, the remaining three ordinances were vague about the prohibition to be applied. Two of these ordinances, those for Kansas City, KS, and Topeka, $\mathrm{KS}$, were very similar and likely were drawn up with knowledge of the other. They resolved, with no further discussion, that the city involved should "utilize alternatives wherever possible." 29 The ordinance adopted by Milwaukee required that the disclosure of a bidder's relationship with South Africa be reviewed "for whatever policy implications that might be indicated and be

23. Alameda, CA (five percent or $\$ 5,000$, whichever is less); Oakland, CA (five-point-one percent); Sacramento, CA (five percent); Fort Collins, CO (five percent); New York, NY (five percent) and Yonkers (five percent).

24. Washington, D.C., §1002a(A).

25. Id. $\S 1002 \mathrm{a}(\mathrm{A})$.

26. Hennepin County, MN; and Sonoma County, CA.

27. Chicago, IL (eight percent); and Richmond, CA (five percent or $\$ 25,000$, whichever is less);

28. East Lansing, MI, and Madison, WI.

29. Kansas City, KS, and Topeka, KS. 
available as a public record to all interested citizens." 30 A City of Milwaukee summary of the disclosure statements received for the second quarter of 1986 indicates that forty-two firms provided disclosures and entered into procurement contracts with the city for an amount of business totaling almost seven million dollars. One of the forty-two bidders-receiving a contract-disclosed a relatively minor relationship with South Africa. Yet another bidder-also receiving a contract-is indicated as not providing a disclosure at all, although the summary indicated that it intended to do so shortly. ${ }^{31}$

The San Diego, CA ordinance, which had two operative sections, deserves brief mention. First, it directed the City Manager to "forbear" from making purchases from companies with operations in San Diego when the purchase was less than $\$ 500$. Although "forbear" is a somewhat unusual term, the City Manager in practice regarded it as a total prohibition. ${ }^{32}$ This aspect of the ordinance is included in Table 3 as a total prohibition. The second operative section of the ordinance is curious. It required bidders on contracts with a value over $\$ 10$ million to certify that they were "in compliance with Public Law 99-440," the 1986 Federal Anti-Apartheid Act. The interesting question is how to look at this requirement in terms of the nature of the prohibition. In practice, it may have been the equivalent of a total prohibition in the sense that if a bidder was unwilling to provide such a certification then a contract might not have been awarded..$^{33}$

A clear lesson from this recitation is that the ordinances on their face had quite different capacities for possible interference with the foreign affairs of the United States. Would the analysis in the Crosby case be applicable to selective procurement ordinances as mild as that adopted by Madison or Milwaukee? In the Zschernig case, the U.S. Supreme Court found portions of the Oregon probate statute had "a direct impact upon foreign relations and may well adversely affect the power of the central government to deal with those problems." 34 Justice Douglas, writing for the Court, acknowledged that there were other areas of state or local action that had an impact on foreign relations, but that often such actions had no more than "some incidental or indirect effect in foreign countries." 35 This group of actions the court termed "the category of a diplomatic bagatelle." 36 An important observation of this study is that a significant number of the ordinances may be little more than diplomatic bagatelles. The Milwaukee

30. Milwaukee, WI.

31. See "City of Milwaukee South Africa Disclosure Statements Report from 2nd Quarter-5/ 12/86-8/11/86 Firms That Responded this Period," an enclosure to Letter of Edward A. Witkowski, Purchasing Agent for the City of Milwaukee dated December 1, 1986, copy on file with the author.

32. An exception to this prohibition denied it of all effect in practice; see, e.g., text accompanying note 71 .

33. The City of San Diego considered adoption of a more encompassing selective procurement ordinance, but was informed by its City Attorney that, in his opinion, the City Charter did not permit the City to exclude a low bidder from receiving a contract because of its involvement in South Africa. See Memorandum of the City Attorney to Jack Thorpe, Purchasing Agent dated Nov. 20, 1986 , on file with the author.

34. Zschernig, 389 U.S. at 441.

35. Id. at 434 .

36. Id. at 435 . 
ordinance did no more than create a public record, and therefore perhaps public knowledge, concerning the business operations in South Africa of the City's suppliers. ${ }^{37}$

Finally, it is important to note that the ordinances often had exceptions to the prohibitions. The detailed ordinances contained exceptions when, for example, the tainted company was the sole bidder or when the prohibition would pose a substantive financial hardship for the city. For example, the Pittsburg ordinance contained a common set of exceptions:

The prohibitions contained in this section can be waived if they are:

(1) inconsistent with existing laws;

(2) inconsistent with other obligations of current contractual relationships;

(3) would constitute undue financial burden on the City;

(4) or no other source of supply exists. ${ }^{38}$

The exceptions to San Francisco ordinance's total prohibition on the City's purchase of goods/services from affected companies are more detailed but in many respects the same as those for Pittsburg:

(1) Contract entered into prior to effective date of the Ordinance (9/4/86);

(2) Contracts for $\$ 5000$ or less;

(3) "Not South Africa Free" company is sole source;

(4) No source is capable of compliance;

(5) Application of prohibitions is inconsistent with other contractual obligations;

(6) City will incur financial loss or breach fiduciary duty (ten percent differential or $\$ 50,000) .{ }^{39}$

Many of the above exceptions are to be expected. Indeed, the surprising point is that seven of the "total prohibition" ordinances did not have any exceptions. ${ }^{40}$ (Five of these are among the seven ordinances listed above as being of questionable seriousness.) The operation of the exceptions in practice is beyond the scope of this study. A few instances of practice, however, indicate the exceptions were utilized. For example, a seemingly large number of exemptions from the Los Angeles selective procurement ordinance were noted in the press. One report indicated 300 exemptions between the adoption of the ordinance in July 1986 and May of $1988 .{ }^{41}$ More dramatically, a City Administrative Officer's report on the ordinance indicates that there were 348 exemptions granted between July 1 and December $31,1988 .{ }^{42}$

37. Although such an ordinance might be seen in terms of Zschernig as affecting "international relations in a persistent and subtle way," Zschernig, 389 U.S. at 440, an action of a city that only generates public information would more likely be protected by the Constitution. See Michael Shuman, Dateline Main Street: Local Foreign Policies, 65 ForeIGN POL'Y 154, 162-63 (Winter 1986-87).

38. Pittsburgh, PA.

39. San Francisco, Cal., Regulations Governing the Implementation of Article XIX of the San Francisco Administrative Code (October 19, 1987) at 8, para. 3.

40. Camden, NJ; Charleston, SC; Fairmont, WV; Gary, IN; Omaha, NE; Stockton, CA; and Tucson, AZ.

41. Richard Simon, Firm Exempted from Anti-Apartheid Law, L.A. Times, May 14, 1988 Part 2 at page 3.

42. City Administrative Officer, City of Los Angeles South Africa Contracting Ordinance Semiannual Report of Exemptions, referrals to City Council and Barriers or Impediments to the Efficient and Full Enforcement of the Ordinance-July 1 through Dec. 31, 1988, transmittal date of February 27, 1989, copy on file with author. 


\section{E. The Identification Mechanism}

Eighteen ordinances identified the bidders' relationships with South Africa by requiring either a "Disclosure Statement," "Affidavit," "Declaration" or "Contract Stipulation." 43 Three ordinances identified bidders who conduct business in or with South Africa via a list prepared by the city from official sources. ${ }^{44}$ Three other ordinances employed both the list and declaration mechanisms. ${ }^{45}$ The Washington, D.C. ordinance, for example, identified bidders by both means. It provided for the determination that a bidder is a "South Africa related-company" if its required affidavit indicated it had "business interests in" South Africa or if the bidder was included on the "prohibited list" maintained by the City and had not successfully petitioned for removal from that list. ${ }^{46}$ The remaining twelve ordinances were completely silent on how the relationship of the bidder to South Africa was to be ascertained. ${ }^{47}$

The San Francisco ordinance required the Contracting Officer to obtain an affidavit, in the form prescribed by the City, from the bidder prior to contracting for goods or services. ${ }^{48}$ In addition, the ordinance set forth a specific compliance clause that was required to be incorporated as a material condition in each contract for the supply of a commodity to the City. ${ }^{49}$

\section{F. The Scope of Examination}

As the selective procurement ordinances were adopted more widely, cities and the non-governmental organizations promoting such ordinances adopted the view that the web of ordinances should not only widen, but also deepen. "To some extent, people are still learning how to create selective purchasing legislation," said Richard Knight of the American Committee on Africa in 1989. ${ }^{50}$ Thus as new selective procurement ordinances were considered, one focus was to ensure that the ordinances asked the right questions of the bidder. "But if a subsidiary of that corporation-or a parent company-is conducting business in South Africa, the city won't necessarily find out because often the question is never asked." ${ }^{51}$ The sense that a deeper examination was needed was also fueled by the suspicion that U.S. companies selling their assets and operations in

43. Tucson, AZ; Los Angeles, CA; Richmond, CA; Sacramento, CA; San Francisco, CA; Sonoma County, CA; Fort Collins, CO; Chicago, IL; State of Maryland; Hennepin County, MN; Omaha, NE; Newark, NJ; New York, NY; Yonkers, NY; Pittsburgh, PA; Houston, TX; Fairmont, WV; and Milwaukee, WI.

44. Alameda, CA; Oakland, CA; and Madison, WI.

45. Berkeley, CA; West Hollywood, CA; and Washington, D.C.,

46. Washington, D.C., \$1003(a).

47. San Diego, CA; Stockton, CA; Gary, IN; Kansas City, KS; Topeka, KS; College Park, MD; East Lansing, MI; Camden, NJ; Rochester, NY; Raleigh, NC; Charleston, SC; and Richmond, VA.

48. San Francisco, Cal., Regulations Governing the Implementation of Article XIX of the San Francisco Administrative Code (October 19, 1987) at 8.

49. Id.

50. Quoted in, Chipping Away at the Divestment Con Game, Bull. Mun. Foreign Pol'y 30, Autumn 1989.

51. Id., quoting Stephen Davis of the Investor Responsibility Research Center. 
South Africa actually might be engaging in "corporate shell games" and thereby maintaining an indirect interest in South Africa. ${ }^{52}$ The focus of the early ordinances primarily on the bidder alone did not address such a possibility. More generally, a focus on only the bidder's status led to troubling applications of local ordinances. For example, the Pittsburg ordinance placed a total prohibition on procurement from bidders that did business in and with South Africa. The ordinance did not examine beyond the bidder. In one instance, Xerox Corporation is reported to have been the low bidder on the supply of copiers to the Pittsburg School Board but to have lost the bid to Monroe Systems because of Xerox's business in and with South Africa. The relevant twist is that Xerox was reported to have argued in vain that Monroe Systems was merely the local distributor for a Japanese corporation that did business in South Africa and which, unlike Xerox, was not in compliance with the Sullivan Principles. ${ }^{53}$

Most ordinances, particularly the earlier ones, inquired only into the relationship of the bidder to South Africa. Nine ordinances addressed the South African relationships of subsidiaries of the bidder. ${ }^{54}$ Four of those nine and one further ordinance inquired into the South African relationships of affiliates. ${ }^{55}$ Again, four of the previous nine and one further ordinance examined the South African relationships of the parent company. ${ }^{56}$ In the case of Los Angeles, the low bidder for a $\$ 12$ million sewage treatment contract, the firm of Daniel Mann Johnson \& Menderhall, ran into a problem under the City's selective procurement ordinance when it came to light that the bidder's parent, Ashland Oil, sold its products in South Africa through a distributor. Ashland Oil is reported to have pledged to terminate the distributorship in three months, and the bidder received the contract. ${ }^{57}$ Finally, two of the last mentioned ordinances, namely those of San Francisco and Los Angeles, and two further ordinances, examined the South African relationships of suppliers to the bidder. ${ }^{58}$ In total, thirteen of the ordinances looked in some way beyond the bidder.

Under the implementing regulations for the San Francisco ordinance, for example, the City deemed the bidder to be "Not South Africa Free" if the bidder:

(1) owns $5 \%$ or more of the stock or other equity of another company which does business in or with South Africa;

(2) is $5 \%$ or more owned by another company which does business in or with South Africa (Note: the 5\% standard applies to all "links" in the parent-subsidiary chain);

52. Local Boycotts, supra note 8. See, e.g. James M. Leas, I.B.M. Still Bolsters Apartheid, N.Y. Times, Apr. 4, 1988, at A19; James Reilly, I.B.M. Still Proud of Role in South Africa, N.Y. Times, Apr. 13, 1988, at Al8.

53. See Local Boycotts, supra note 8.

54. Alameda, CA; Los Angeles, CA; Oakland, CA; San Francisco, CA; Fort Collins, CO; District of Columbia; State of Maryland; New York, NY; and Houston, TX.

55. Alameda, CA; Oakland, CA; and Charleston, SC.

56. Los Angeles, CA; San Francisco, CA; and District of Columbia.

57. See Local Boycotts, supra note 8.

58. The San Francisco ordinance (as explained in the Interim Informal Guidance) is somewhat broader than the Los Angeles ordinance, which examines "exclusive distributors." 
(3) has formed a Partnership or Joint Venture with a second company to form a third entity for the purpose of assisting the second company's business in or with South Africa;

(4) is a distributor of goods which are manufactured by a South Africa "tainted" company.

Ironically, as discussed within, because of an overly rigid design the San Francisco ordinance's search for even relatively attenuated connections to South Africa resulted in that ordinance having less effect.

\section{G. Reintegrating the Comparison}

Pulling these comparisons back together, it can be seen that the ordinances had five basic types, each with several subtypes. Basically there are four types flowing from a two by two matrix of total prohibition versus contract preference and a "doing business" trigger versus all other triggers. The fifth type encompasses the ordinances that were essentially symbolic and of only de minimus direct effect. These types are summarized in Table 3.

Table 3 - Summary of the Types of Ordinances

\begin{tabular}{|c|c|c|c|c|}
\hline Type of Ordinance & \multicolumn{4}{|c|}{ Subtypes } \\
\hline $\begin{array}{l}\text { Type 1: } \\
\text { Total Prohibition on } \\
\text { Those "Doing } \\
\text { Business" in or with } \\
\text { South Africa } \\
13\end{array}$ & $\begin{array}{l}3 \text { Ordinances were detailed } \\
\text { Pittsburg, PA, 1985 } \\
\text { San Francisco, CA, } 1986 \\
\text { Los Angeles, CA } 1986\end{array}$ & \multicolumn{2}{|c|}{$\begin{array}{l}6 \text { Ordinances were brief, yet } \\
\text { apparently serious } \\
\text { Newark, NJ, 1984 } \\
\text { Richmond, CA, 1985 } \\
\text { Tucson, AZ, 1985 } \\
\text { Berkeley, CA, 1986 } \\
\text { West Hollywood, CA, } 1986 \\
\text { Fairmont, WV, 1986 }\end{array}$} & $\begin{array}{l}4 \text { Ordinances were brief and } \\
\text { somewhat vague } \\
\text { Gary, IN, } 1985 \\
\text { Charleston, SC, } 1985 \\
\text { Camden, NJ, 1985 } \\
\text { Richmond, VA, } 1985\end{array}$ \\
\hline $\begin{array}{l}\text { Type 2: } \\
\text { Total Prohibition for } \\
- \text { one or more of the } \\
\text { following triggers - } \\
\text { (1) Those Who Do } \\
\text { Business with } \\
\text { Apartheid Enforcing } \\
\text { Agencies, (2) When } \\
\text { the Goods Originate } \\
\text { from South Africa or } \\
\text { (3) Noncompliance } \\
\text { with the Sullivan } \\
\text { Principles } \\
7\end{array}$ & $\begin{array}{l}3 \text { Ordinances were triggered } \\
\text { by all three circumstances } \\
\text { Rochester, NY, } 1985 \\
\text { Raleigh, NC, } 1986 \\
\text { Chicago, LL, } 1986\end{array}$ & \multicolumn{2}{|c|}{$\begin{array}{l}3 \text { Ordinances were triggered by } \\
\text { the origin of the goods } \\
\text { College Park, MD } 1985 \\
\text { Omaha, NE, 1985 } \\
\text { Stockton, CA } 1986\end{array}$} & $\begin{array}{l}\text { 1 Ordinance was triggered by } \\
\text { the origin of the goods and } \\
\text { noncompliance with the } \\
\text { Sullivan Principles } \\
\text { State of Maryland, } 1986\end{array}$ \\
\hline $\begin{array}{l}\text { Type 3: } \\
\text { Contract Preference } \\
\text { Against Those "Doing } \\
\text { Business" in or with } \\
\text { South Africa } \\
4\end{array}$ & \multicolumn{2}{|c|}{$\begin{array}{l}3 \text { Ordinances had specific preference } \\
\text { percentages } \\
\text { Oakland, CA, } 1985 \\
\text { Alameda County, CA, } 1986 \\
\text { Sacramento, CA, } 1986\end{array}$} & \multicolumn{2}{|c|}{$\begin{array}{l}1 \text { Ordinance awarded demerits } \\
\text { Washington, D.C., } 1986\end{array}$} \\
\hline $\begin{array}{l}\text { Type 4: } \\
\text { Contract Preference } \\
\text { Against - one or } \\
\text { more of the following } \\
\text { triggers - (1) Those } \\
\text { Who Do Business } \\
\text { with Apartheid } \\
\text { Enforcing Agencies, }\end{array}$ & \multicolumn{2}{|c|}{$\begin{array}{l}3 \text { Ordinances were triggered by either the } \\
\text { origin of the goods or business with Apartheid } \\
\text { enforcing agencies } \\
\text { New York, NY, } 1985 \\
\text { Yonkers. NY, } 1985 \\
\text { Houston, TX, } 1986\end{array}$} & \multicolumn{2}{|c|}{$\begin{array}{l}1 \text { Ordinance was triggered by all three } \\
\text { circumstances } \\
\text { Ft Collins, CO, } 1985\end{array}$} \\
\hline
\end{tabular}




\begin{tabular}{|c|c|c|c|c|c|}
\hline $\begin{array}{l}\text { Type } 4 \text { (cont'd) } \\
\text { (2) When the Goods } \\
\text { Originate from South } \\
\text { Africa or (3) } \\
\text { Noncompliance with } \\
\text { the Sullivan } \\
\text { Principles } \\
4\end{array}$ & & & & & \\
\hline $\begin{array}{l}\text { Type } 5 \\
\text { De Minimus Effect } \\
\text { Against (1) in all } \\
\text { cases those "Doing } \\
\text { Business" in or with } \\
\text { South Africa and (2) } \\
\text { in one case also for } \\
\text { Noncompliance with } \\
\text { the Sullivan } \\
\text { Principles. } \\
8\end{array}$ & $\begin{array}{l}2 \text { Ordinances } \\
\text { required only a } \\
\text { Mayoral } \\
\text { statement of } \\
\text { concern } \\
\text { Madison, WI, } \\
1976 \\
\text { Et Lansing, MI, } \\
1977\end{array}$ & $\begin{array}{l}2 \text { Ordinances } \\
\text { required only that } \\
\text { the City use } \\
\text { "alternatives } \\
\text { wherever } \\
\text { possible" } \\
\\
\text { Kansas City, KS, } \\
1985 \text { Topeka, KS, } \\
1986\end{array}$ & $\begin{array}{l}2 \text { Ordinances had } \\
\text { a preference if } \\
\text { low bids were tied } \\
\text { Hennepin County, } \\
\text { MN, } 1985 \\
\text { Sonoma County, } \\
\text { CA, } 1986\end{array}$ & $\begin{array}{l}1 \text { Ordinance } \\
\text { required only } \\
\text { certification by } \\
\text { bidder that it } \\
\text { complied with } \\
\text { Federal } \\
\text { restrictions and } \\
\text { that the City } \\
\text { "forbear" from } \\
\text { purchases from } \\
\text { bidders doing } \\
\text { business in South } \\
\text { Africa when } \\
\text { below } \$ 500 \\
\\
\text { San Diego. CA, } \\
1987\end{array}$ & $\begin{array}{l}1 \text { Ordinance } \\
\text { required } \\
\text { disclosure "for } \\
\text { whatever policy } \\
\text { implications that } \\
\text { might be } \\
\text { indicated } \\
\text { Milwaukee, WI, } \\
1985\end{array}$ \\
\hline
\end{tabular}

An important conclusion to be drawn from the Table is that a significant number of the ordinances had little effect. Eight of the ordinances by their terms have a minimal sanction. A further five ordinances were triggered only when the origin of the goods to be purchased was South Africa, a rare situation. ${ }^{59}$ To determine the effect of the remaining ordinances, a much closer examination would be needed into the implementation of the ordinances, including the application of the various exceptions, and into whether the mere existence of an ordinance caused tainted companies to refrain from bidding. The limited findings I made in this regard, and report in Part II, suggest that many of the remaining twenty-three ordinances also had little practical effect.

\section{H. Situating the Burma Statute}

In terms of the patterns outlined, the 1996 Massachusetts Burma statute is relatively moderate. The statute did not call for a total prohibition, but rather gave a preference to bidders that did not have the specified relationship to Burma. As with a number of the South African ordinances, the statute contained the language of a total prohibition: "a state agency or other entity may not procure goods or services from...." As to the circumstance that triggered application, the statute looked to whether the bidder was doing business in Burma; this was determined from a list constructed by the Secretary of Administration and Finance.

59. A further eight ordinances, in addition to the origin of the goods trigger, looked to whether the bidder did business with the Apartheid enforcing agencies or did not comply with the Sullivan Principles for its business operations in South Africa. It is not known how often these situations arose. One reported example involved sales by General Motors of cars and trucks to the South African police which GM reportedly terminated when those sales raised questions under the New York City selective procurement ordinance. See Local Boycotts, supra note 8. 
In terms of the Table 3 scheme, Massachusetts's Burma statute thus would be a Type 1. But, as was the case in some of the South African Type I ordinances, an exception to the total prohibition on procurement makes clear that the prohibition is de facto a contract preference, that is, under the statute, an agency may not procure goods or services from the tainted bidder unless the other qualifying bids are more than ten percent greater.

II.

Pathologies

\section{A. Perception and Reality}

It is crucial to recognize that all parties have an interest in overstating both the number of ordinances and their potential impact. It was surprising to me at first to see how difficult it was to identify precisely which cities had adopted selective procurement ordinances, never mind collecting copies of such ordinances. The perception generated in the media, and by those both for and against such ordinances, was that there were many ordinances and that they could have a serious impact on business or South Africa. The precision of the lists was not important in this calculus. What was important was that the number of cities on the list was as large as possible and that their collective impact appear substantial. The reality was that some cities mentioned in a public source were found not to have a selective procurement ordinance, although in most instances they did have some ordinance relating to South Africa. ${ }^{60}$ Moreover, as stated above, a significant number of the ordinances had a de minimus sanction, little chance of effect because of a narrow scope of operation, or some broad exceptions which-depending on their implementation-potentially could deny the ordinance of force. The reality, rather than the perception, is crucial to understanding the ordinances.

\section{B. Democratic, But...}

One line of argumentation concerning municipal involvement in foreign affairs depicts such action as a desirable expression of democracy. Perhaps it is; my purpose here is not to question that argument per se. A close look at the ordinances, however, leads one to ask who is the demos, the people, that is expressing its view? In general, it need be seen that such ordinances in practice are not a decentralized expression of the American people, but rather an expression of a rather small number of subnational entities. Moreover, since some of the ordinances had more significance than others, we need ask which jurisdictions adopted which ordinances.

First, it is important to emphasize that only a very small number of local governments in the nation adopted selective procurement ordinances relating to South Africa.

60. See supra note 8 . 
Second, the ordinances likely to be most effective were those of cities with substantial procurement budgets that could be withheld. In other words, the larger cities are the ones that count in this game. The thirty-six originating jurisdictions are comprised of thirty-two municipalities, three counties, and one State. The thirty-two cities represent the full range of size. Roughly comparing the size of the thirty-two originating municipalities in terms of their populations in the middle of the 1980s (which also may be a fair proxy for the size of their respective procurement budgets), eight of the cities had populations of over 500,000 , seventeen had populations between 100,000 and 500,000 , and seven had populations less than $100,000 .^{61}$ The eight large cities to adopt selective procurement ordinances were Los Angeles, San Diego, San Francisco, Chicago, New York, Houston, Washington, D.C., and Milwaukee. The sanctioning power of the local selective procurement ordinances resided in these larger municipalities. ${ }^{62}$ Moreover, if larger cities can be said to be more liberal in their politics than rural areas, then such ordinances empower a particular viewpoint of American society. It is not clear that it is necessarily representative of the country generally. ${ }^{63}$

Third, it is not clear how other cities, which take an opposing view or which believe that matters should be left to the federal government, can take an action of equal weight, i.e., an action that is more than a statement of their view.

Fourth, and supportive of these speculations, not only are the local governments listed in Table 1 a small percentage of the total number of such political entities in the United States, but there is a not insignificant overlap between the local governments contained in Table 1 and the local governments that reportedly adopted some sanction concerning Burma. One source indicates that "USAEngage" listed four states and twenty-four cities or counties as of March 2000 having some sanction related to Burma. ${ }^{64}$ Bearing in mind that a lesson from the present study is that such lists are somewhat inaccurate, I note that eight of the twenty-four cities and counties are also local governments that adopted selective procurement ordinances regarding South Africa. ${ }^{65}$

61. Population data taken from the U.S. Bureau of the Census, 1980 Census of Population, Supplementary Report, Metropolitan Statistical Areas (PC80-S1-18); Statistical Abstract 1988; and County and City Data Books, U.S. Bureau of the Census 1988 (1986 data).

62. A similar observation can be made with the states. In particular, it is perhaps noteworthy that a significant percentage of the ordinances were adopted by cities in California. Nine of the thirty-four ordinances adopted by municipalities, or twenty-six percent, were adopted by cities in California. Three of the eight cities having a population greater than 500,000 in the mid-1980s were cities in California.

63. For what is in essence a public choice theory approach to the politics of municipal foreign policy, see Insight Magazine Warns of Cities "Left" Tilt on Foreign Policy, Bull. OF MuN. ForeIGN AF. 4, Spring 1987, and the article discussed therein.

64. Terrence Guay, Local Government and Global Politics: The Implications of Massachusetts" "Burma Law," 115 Pol. ScI. Q. 353, 357 (2000).

65. In addition, recalling the observation in note 62 , nine of the twenty-four cities and counties are in California. 


\section{Implementation and the Limitations on Municipal Foreign Affairs}

The longer and more detailed ordinances, an indicator in some respects of the seriousness of the ordinances, were adopted by the larger, rather than smaller, municipalities. In part, this circumstance likely reflects not only the burden of drafting such an ordinance, but also the burden on any locality of administering a more serious, and correspondingly complicated, set of selective procurement regulations. It costs money to run these ordinances. Concerning the Los Angeles ordinance, for example, the chief administrative analyst there stated it cost the City $\$ 220,000$ (representing three part-time salaries) for a year and a half of administering their selective purchasing ordinance. In the case of San Francisco, it was reported that the chief administrator of the selective purchasing and contracting program had submitted a budget request for $\$ 398,000$, but received only $\$ 107,000$ from the Mayor's office. ${ }^{66}$ The same report went on to state that implementation was lagging a year and a half after adoption. ${ }^{67}$ It also takes time to administer a serious ordinance. John Hornsby, the purchasing director for Berkeley, CA, was reported to have said that "[i]t takes up a tremendous amount of time, because we have to check and double check ... [i]t does preclude you from completing day-to-day operations more efficiently." 68 It is not only the larger municipalities that have the purchasing power to count; it likely is only the larger municipalities that can afford to count.

\section{The Network of Municipal Foreign Affairs}

The wording of the ordinances confirms a common observation; networks must exist to explain the repeating patterns in these ordinances and, for the most part, these coordinating networks were supplied by nongovernmental organizations. There is a clear sense when reading the ordinances that there existed model selective procurement ordinances which circulated around the country and evolved over time. There was, for example, an evolution tending toward an apparent increased severity. Not only was the local political effort that called for the adoption of such ordinances usually networked into a national civic effort, but local governments also were aware of what other cities had done or were contemplating. In some cases, nongovernmental organizations supplied model ordinances or copies of the ordinances adopted by other cities. In other cases, cities may have been communicating directly with other cities, seeking their experience. Some ordinances refer in the preamble to the actions of other specific cities. Committees of the Sacramento City Council instructed its City Attorney "to prepare a draft ordinance similar to the ordinance adopted by the City of Oakland." ${ }^{69}$ Topeka, KS, adopted the same ordinance passed by Kansas

66. San Francisco Evaluates Anti-Apartheid Ordinance, BuLl. OF MUN. Foreign POL'y 48, Autumn 1987.

67. Id.

68. James Rainey, Apartheid Policy-A Dilemma for West Hollywood, L.A. Times, Dec. 19, 1985, part 2, at 1.

69. Memorandum of the Office of the City Attorney for Sacramento to the Sacramento City Council, dated December 26, 1986, copy on file with the author. 
City. The Raleigh, NC ordinance referred to the Rochester, NY ordinance, the latter having clearly inspired the former. The Houston, TX ordinance followed quite closely the language of the ordinance adopted by New York City.

\section{E. The Symbolism of Some Selective Procurement Ordinances}

On a spectrum running from symbolic statement to legislative sanction, a local government resolution condemning the human rights practices of a foreign country would be placed toward the symbolic end. A selective procurement ordinance would be placed more toward the legislative sanction end of the spectrum. This study suggests several ways in which selective procurement ordinances are more symbolic than might be thought.

First, at least eight of the thirty-six ordinances are explicitly of minimal effect or are so non-specific that they must be thought of as primarily symbolic statements.

Second, despite the fact that the ordinances attempted to become tighter and more substantial over time, it is interesting that none of the municipalities amended its ordinance in order to strengthen it. (One of the few amendments was that adopted by West Hollywood; that amendment, however, did not make the amendment stronger but rather added exceptions to what the City had come to realize was an overly strict first version. ${ }^{70}$ ) Once a city adopted an ordinance, it apparently stopped consideration of making its action more effective. It may be that in time, municipalities would have revisited and strengthened their ordinances. But it is curious that not one did so in the period encompassed in this study. For me, this suggests that selective procurement ordinances, at least for some cities, were a means to make a statement about South Africa that appeared to have more substance than merely a resolution expressing a city's condemnation of the policy of apartheid. A selective procurement ordinance implies a willingness to sanction those supporting the apartheid system and a willingness to bear the added costs. In this sense it has substance, is noted by the press, and is added to the total number of cities with such ordinances. There was much less payoff, however, to tightening a city's ordinance.

Third, the ordinances adopted were implemented with varying degrees of intensity. For example, Washington, D.C., one of the large municipalities, had a relatively strict and detailed ordinance. It provided that it was "to be implemented by regulations." I learned to my surprise from interviews with city officials in Washington, D.C. that as of 1989 , three years after its passage, the ordinance was not in operation because implementing regulations had not been adopted.

70. The city of West Hollywood amended its ordinance to allow the city to purchase goods from companies who do business in South Africa when "[t] the special characteristics of (a) particular product offered by the firm are necessary for the efficient operation of the city or the health, safety and welfare of the public and no comparable product is available at a reasonably comparable price." This exception was commonly present in the more detailed ordinances. See James Rainey, Apartheid Policy-A Dilemma for West Hollywood, L.A. Times, Dec. 19, 1985, part 2, at 1; James Rainey, W. Hollywood Council OKs Modified Policy on Divesture, L.A. Times, Jan. 11, 1986, part 2, at 1 . 
Fourth, because of the operation of the exceptions to the prohibition on procurement, some ordinances in fact were quite weak. In the case of San Diego, a Senior Purchasing Agent for the City in 1989 stated that the ordinance had "no effect on my life whatsoever." 71 The Agent remarked that the ordinance's prohibition on making purchases under $\$ 500$ from companies that had "business operations" in South Africa was basically short-circuited by the "sole source" exception. ${ }^{72}$

Fifth, it was difficult to make the ordinances stricter. For example, the apparent growing strictness of new ordinances over time disguised the fact that, for at least one, this increased strictness resulted in a weaker ordinance. One way the ordinances, at least superficially, became more strict was by the inclusion of a definition of "doing business in or with South Africa" that was more exacting and probing. The prime example, cited above, was the San Francisco selective procurement ordinance. The San Francisco ordinance went so far as to provide that if a bidder had a five percent interest in a subsidiary or an affiliate, or if five percent of it was owned by a parent, who does business in South Africa, then the bidder was also, for purposes of the ordinance, doing business in South Africa. ${ }^{73}$ But in the case of the San Francisco ordinance (as in Massachusetts's Burma statute), there is an additional provision that states if none of the bidders on a particular contract are South Africa clean, then the city may procure the goods or services from any of the bidders. The irony is that as the San Francisco ordinance adopted a superficially very strict approach, it in fact was quite weak because virtually all of the bidders were tainted by a five percent connection to a company doing business in or with South Africa. Every major office supply company was tainted. Every major oil company was tainted. Everyone was at least five percent tainted. Consequently, everyone was clean and everyone could bid. In other words, the exception made no distinction between a felony and a misdemeanor; a remote taint was as much of a taint as direct and substantial business in South Africa.

Perhaps the San Francisco ordinance problem could have been addressed by redrafting. The Richmond, CA ordinance, for example, provided that if all the bidders were tainted, then the contract should be granted to the bidder "which conforms to the greatest extent." However, in the closely scrutinized world of governmental procurement, such discretionary and subjective standards are often avoided. More importantly, the difficulty of constructing a more exacting ordinance goes beyond mere redrafting. On the one hand, it was necessary to examine the relationship of the bidder to other entities and their relationship to the target country. On the other hand, it need be recognized that a tremendous cost was placed on all bidders, not only tainted ones, to ascertain, in most cases negatively, their corporate status.

71. Interview of Ann Stock by Paul Startz, as recorded in memorandum dated May 9, 1989, on file with author.

72. Id

73. See supra text accompanying note 38 . 
In addition, it should be recognized that such a wide examination can be counterproductive to the overall objectives of the ordinance. Assume that both Company $\mathrm{X}$ and Company $\mathrm{Y}$ do business with South Africa. Company X has extensive business operations in South Africa. Company $Y$ has very little business with South Africa. Company $X$ owns five percent of Company Y. Company $Y$ seeks to do business with San Francisco. Company $Y$ would be willing to end its business with South Africa in order to gain the possibility of business with San Francisco-an objective of the ordinance. Company X is not willing to end it business with South Africa in order to further the business of company $Y$ and it is not willing to sell its five percent interest in company $Y$ unless a substantial markup on the value of that interest is paid. Since San Francisco will regard company $\mathrm{Y}$ as tainted even if it terminates it business sales to South Africa because it is five percent owned by company $\mathrm{X}$, company $\mathrm{Y}$ has two options. Pay a substantial markup to the company $X$ thereby rewarding the company more involved in South Africa-not an objective of the ordinance. Alternatively, it can not bid for San Francisco business and keep its business with South Africa-also not an objective of the ordinance.

\section{F. The Bootlegger-Prohibitionist Alliance}

Politics gives rise to strange bedfellows. Both the prohibitionist and the bootlegger have an interest in seeing liquor outlawed in a given jurisdiction. Both environmentalists and U.S shrimp fishermen supported U.S. import sanctions placed on shrimp caught abroad in a manner endangering sea turtles. In the case of selective procurement ordinances, support comes most apparently from groups concerned with the practices of the target country. But there are other complementary forces possibly present.

It should be recalled that a different vein of state and local activism possibly impinging on foreign affairs involved a variety of "Buy America," or even "Buy State," statutes. ${ }^{74}$ The important point for this study is that selective procurement ordinances distinguishe between potential bidders and thus affect competition. To the extent that the foreign or large U.S. bidder is more likely to have the specified relationship with South Africa and thereby be tainted, small

- local suppliers will benefit from such ordinances. In this sense, it should not be a surprise that as I listened to a tape recording of a particular city council's debate prior to adoption of its resolution, there was brief, but nonetheless open, discussion of the fact that such an ordinance would likely benefit small local businesses that, unlike the large corporate bidders, would be unlikely to have any relationship with South Africa.

74. See, e.g., Richard Bilder, East-West Trade Boycotts: A Study in Private, Labor, Union, State and Local Interference with Foreign Policy, 118 U. PA. L. REv. 841 (1970); Earl H. Fry, State and Local Governments in the International Arena, 509 THE ANNALs of THE AMERICAN ACADEMY $118,121-22$ (1990). 


\section{G. Externalities and Unexpected Costs}

The two mechanisms employed to identify tainted bidders were either an affidavit from the bidder, in some instances signed by the head of the company, or the use of a list constructed by the City or drawn from some other source.

Administratively, affidavits are the easier mechanism for the city. They transfer the burden of identification to the bidders. However, interviews with company officials revealed that the affidavit can generate a great deal of pressure within a company. If the degree of examination, for example, extends beyond the bidders to its suppliers, its parents, etc., then the bidder needs to undertake an extensive analysis. It needs to check with its affiliates and subsidiaries to see whether they conduct any business in or with South Africa. An affidavit, carrying with it penalty for perjury, was appropriately seen by bidders I spoke with as a serious matter. Companies indicated they would spend a significant amount of time and money so that they might submit an affidavit with confidence of its accuracy. But, some proportion of the bidders performing this examination, depending upon the target country involved and the type of procurement involved, will not be tainted. By using the affidavit mechanism, a city placed significant (and recurring, since the business practices of affiliates could change) costs on all bidders. A particularly troubling demonstration of this cost involved Washington, D.C. In that case, the city had a rather strict detailed ordinance that utilized the affidavit mechanism. As described above, implementing regulations, at least as of 1989 , had not been adopted and the ordinance had not been implemented. The city official interviewed, however, indicated that although the ordinance had not come fully into operation, the affidavits had been filed by bidders.

\section{III.}

\section{Observing Crosby}

\section{A. Crosby as a Reassertion of Control}

Professor Spiro contrasts the image of the State as a unitary actor with the reality of a globalized world and porous States. I find that image and reality intriguing. The contrast raises the question of how a State may restore, even if selectively, its primacy; of how it might seek to control the behavior of individuals, corporations, and political subdivisions it views as in conflict with its efforts as a unitary actor. In considering these questions, we could ask under what circumstances has a State sought to regain such control; under what circumstances should a State as a normative matter seek such control; and, generally, what are the costs and benefits to the State, to the international community and to the international issue of concern, of the State regaining exclusive control and foreclosing particular sub-national foreign affairs? A crucial observation about the Crosby decision, is that if the State or private plaintiff in a particular instance cares enough to seek to reassert federal control, it is possible. 


\section{B. Crosby and Municipal Interest in Foreign Affairs}

During the mid-1980s, it was asked whether municipalities in general were becoming more interested in foreign affairs or whether the movement was driven by the particular situation in South Africa and the resonance for the United States of that racial situation. The Burma ordinance demonstrates that municipal and individual concern to be more widespread. It may be that the familiarity cities gained with such ordinances because of South Africa has led to their adoption in other situations. But it also appears that the inclination of some cities to act in foreign affairs is deep and resilient.

Simultaneously, however, the decision in Crosby forces us to ask why there was no plaintiff for a case about the sanctions adopted regarding South Africa. Why did the NFTC not bring a case against the South African sanctions? Striking to me, at that time, was that there was no plaintiff willing to step forward and challenge the South African statutes. Interviews with corporate officials make clear that it was not thought to be politically wise to challenge the municipal actions related to South Africa. Even a trade association as plaintiff was not thought to provide enough political cover. Likely, there was a similar calculus of interest in the federal government. ${ }^{75}$ This yields an important insight into a dynamic between politics and law. It may be that certain municipal actions would be found to impermissibly intrude on the foreign affairs of the United Sates, but if political support for the cause underlying such actions is sufficiently deep and widespread, that fact will militate against any legal challenge. The significance of the intrusion on foreign affairs and the depth of political support for action on the underlying issue will be weighed before the government moves to challenge the municipal action. ${ }^{76}$ The proof of whether it is a truer expression of democracy is whether any plaintiff would risk the wrath of those denied their view.

\section{Crosby and the Dynamics of City Councils}

In listening to tape recordings of city officials discussing the adoption of such ordinances, it was clear that, even if the resolution was adopted unanimously, the debate was often quite close. The dynamic I heard involved a few members of the council very strongly supporting the ordinances, one person opposing and otherwise a great deal of silence. I think it quite open to question whether the dynamic in the room would change if someone had said: "Don't you remember Crosby? You can't do this. It is just going to be knocked down, so why are we going to all this trouble?' It should not be assumed that these ordi-

75. For a discussion, see the comparison made between the South African and Burmese situations in Erika Moritsugu, The Winding Course of the Massachusetts Burma Law: Subfederal Sanctions in a Historical Context, 34 G.W. INT'L L. Rev. 435, 453-58 (2002).

76. During this same time period of this study, the federal government quickly filed a complaint for declaratory and injunctive relief against operation of a City of Oakland, CA, 1988 Nuclear Free Zone ordinance that would have prohibited, inter alia, the transport of radioactive materials on highways crossing the city limits. See United States v. City of Oakland, California, Civil Action No. C 893305 (Sept. 6, 1989). The ordinance in this instance was adopted by citizen initiative. See Bill O'Brien, The Nuclear Offense: Measure T Challenged in Court, Express (May 26, 1989) at 2. 
nances were strongly endorsed by all members of the city governments that adopted them.

III.

\section{CONCLUSION}

In 1993, Harry Scheiber wrote "the category of diplomatic bagatelle . . embraces much of the vaunted paradiplomacy that attracts attention today." 77 The details of the South African selective procurement ordinances basically support Scheiber's view. The reality that emerges from this study is that there were two basic groups of ordinances. First, there were the serious selective procurement ordinances which potentially intruded on the foreign affairs of the United States, which in the case of South Africa were probably no more than one quarter of the ordinances adopted. Second, there were the selective procurement ordinances, which I came to regard as "costly symbols." This is not to say symbols are without value. But neither is it to say that these symbols were without costs.

77. Harry N. Scheiber, International Economic Policies and the State Role in U.S. FEDERALism: A Process Revolution in States and Provinces in the International Economy 65, 82-3 (Douglas M. Brown \& Earl H. Fry, eds., 1993). 